\title{
Kandungan Pigmen Polar Dan Biomassa Pada Mikroalga Dunaliella Salina Dengan Salinitas Berbeda
}

\author{
Ali Djunaedi1*, Chrisna Adi Suryono' dan Sardjito² \\ 'Departemen IImu Kelautan, Fakultas Perikanan dan IImu Kelautan, Universitas Diponegoro \\ 2Departemen Aquakultur, Fakultas Perikanan dan Ilmu Kelautan Universitas Diponegoro \\ JI. Prof. Soedarto, SH. Kampus UNDIP Tembalang, Semarang 50275 \\ Email : alidjunaedi@ymail.com
}

\begin{abstract}
Polar pigments content and biomass of Dunaliella salina are affected by salinity related to osmotic pressure and density of media. This study was to determine the effect of salinity on pigment contents and dried biomass of microalgae D. salina. The cultivation used microalgae derived from Balai Besar Pengembangan Budidaya Air Payau (BBPBAP), Jepara. Research method was the Laboratory study with a Completely Randomized Design (CRD). Consisting of one treatment with five stages of salinity treatments: 20 ppt, 25 ppt, 30 ppt, 35 ppt, and $40 \mathrm{ppt}$ and using three times of repetition. Analysis of pigments used UV-Vis spectrophotometric extracted with acetone as the solvent. Harvesting time was when it reached at the stationair phase using flocculation method. The results showed that salinity had the significant effect $(P<0.05)$ on polar pigment and dry biomass. The treatments of 35 ppt showed that the highest content phycocyanin and allophycocyanin pigments were $11.341 \mathrm{mg} / \mathrm{gram}$ and $9.644 \mathrm{mg} / \mathrm{gram}$ respectively. The highest dry biomass was achieved at $35 \mathrm{ppt}$ salinity treatment at $0.789 \mathrm{gram} / \mathrm{L}$.
\end{abstract}

Keywords: Dunaliella salina, salinity, Polar pigment, Biomass.

\begin{abstract}
Abstrak
Kandungan pigmen polar dan biomassa Dunaliella salina dipengaruhi oleh salinitas yang berkaitan dengan tekanan osmotik dan densitas media. Tujuan dari penelitian ini adalah untuk mengetahui pengaruh salinitas terhadap kandungan pigmen polar dan biomassa kering D. salina. Biota uji diperoleh dari Balai Besar Pengembangan Budidaya Air Payau (BBPBAP), Jepara. Metode penelitian adalah eksperimen laboratoris dengan Rancangan Acak Lengkap (RAL) yang terdiri dari 1 perlakuan dengan 5 taraf perlakuan salinitas, yaitu: $20 \mathrm{ppt}, 25 \mathrm{ppt}, \quad 30 \mathrm{ppt}, 35 \mathrm{ppt}$, dan $40 \mathrm{ppt}$ dengan pengulangan sebanyak 3 kali. Analisis pigmen dengan metode spektrofotometer UV-Vis yang diekstraksi menggunakan larutan aseton. Pemanenan biomassa pada fase stasioner dengan menggunakan metode flokulasi. Hasil penelitian menunjukkan bahwa salinitas berpengaruh terhadap kandungan pigmen dan biomassa kering Dunaliella salina. Perlakuan salinitas 35 ppt menghasilkan kadar pigmen fikosianin dan allofikosianin tertinggi, yaitu $11,341 \mathrm{mg} / \mathrm{gram}$, dan $9,644 \mathrm{mg} / \mathrm{gram}$, serta menghasilkan biomassa kering tertinggi, yaitu 0,789 $\mathrm{gram} / \mathrm{L}$.
\end{abstract}

Kata Kunci : Dunaliella salina, Salinitas, Pigmen polar, Biomassa

\section{PENDAHULUAN}

Mikroalga dapat melakukan biosintesa bahan kimia bernilai tinggi seperti protein, asam lemak tidak jenuh berantai panjang (LC-PUFA) dan pigmen.
Akan tetapi, pertumbuhan mikroalga dan komposisi biokimia yang terbentuk sangat dipengaruhi oleh cara budaya dan kondisi lingkungan budidayanya (Rodriguest et al, 2015). Hal tersebut mengakibatkan pemanfaatan mikroalga bervariasi 
tergantung dari komposisi bahan yang terkandung.

Pemanfaatan mikroalga semakin bervariasi, mulai sebagai bahan pangan, bahan industri biofarmaka, perbaikan lingkungan dan pewarna alami. Mikroalga merupakan sumber pigmen alami yang aman digunakan sebagai zat aditif maupun dalam kosmetik. Beberapa mikroalga dapat menghasilkan pigmen selain dari pigmen hijau yang dihasilkan dari proses fotosintesis. Beberapa pigmen yang umum digunakan dalam industry adalah klorofil, phycobiliprotein dan karotenoid (Azimatun Nur M.M, 2014).

Dunaleilla sp salah satu jenis mikroalga penghasil pigmen yang banyak digunakan sebagai pewarna alami pada industri farmasi, permen, soft drink, kosmetik, dan beberapa industri berbasis bioteknologi lainnya (Hadiyanto \& Azim, 2012). Dunaliella sp adalah alga hijau halotoleran dan meskipun dinding selnya agak kaku, namun tetap dapat tumbuh di lingkungan perairan dengan salinitas dari 0,5-50 mg/l (Jahnke \& White, 2003). Apabila dalam kondisi faktor eksternal yang yang tidak mendukung kehidupannya Dunaliella sp masih dapat melakukan biosintesa bahan yang penting seperti karotenoid; gliserol, vitamin dan protein (Ghoshal et al., 2002).

Salinitas adalah faktor eksternal yang dapat menjadi pemicu utama stress dan penghambat pertumbuhan pada biota darat dan air. Salinitas yang ekstrim akan menyebabkan tekanan osmotik dan atau pertukaran ion yang berpengaruh terhadap metabolisme organisme fotosintetik. Sejumlah penelitian telah menemukan efek salinitas terhadap bioenergetik mikroalga (Loseva NL et al, 2007), produksi lemak (Hounslo E, 2010), pertumbuhan dan produksi karoten (Aras RF et al, 2015), dan pertumbuhan dan komposisi biokimia (Gu Na et al, 2012).

Pigmen adalah zat kimia berwarnawarni yang merupakan bagian dari sistem fotosintesis pada mikroalga. Pigmen dibedakan menjadi tiga kelas: karotenoid, klorofil, dan phycobiliproteins (Barra et al., 2014). Phycobiliproteins merupakan pigmen aksesori dalam alga merah dan cyanobacteria dan merupakan bahan berharga tinggi. Beberapa phycobiliproteins umum termasuk phycoerythrin (PE), phycocyanin (PC), dan allophycocyanin (APC). Pigmen tersebut adalah heterooligomer yang terdiri dari pengelompokan subunit dalam memproduksi sel (Cyanophyta) atau kloroplas (Rhodophyta) yang diatur dalam kompleks yang disebut "phycobilisomes". Phycobiliproteins telah digunakan sebagai pewarna alami; Selain itu, pigmen ini juga secara luas telah digunakan sebagai nutraceuticals atau aplikasi lainnya pada bidang bioteknologi. Penelitian ini bertujuan untuk mengetahui komposisi pigmen Phycobiliproteins pada Dunaleilla sp pada konsisi lingkungan dengan salinitas yang berbeda.

\section{MATERI DAN METODE}

Penelitian dilakukan pada bulan Desember 2015 - Februari 2016. Materi yang digunakan adalah mikroalga jenis Dunaliella salina yang diperoleh dari Balai Besar Pengembangan Budidaya Air Payau (BBPBAP), Jepara. Kultur mikroalga jenis Dunaliella salina dilaksanakan di Laboratorium Pakan Alami, Sedangkan analisa pigmen di Laboratorium Kimia Balai Besar Pengembangan Budidaya Air Payau (BBPBAP), Jepara

Analisis pigmen polar D. salina menggunakan pelarut buffer fosfat $\mathrm{pH} 7$ $\left(\mathrm{NaOH}-\mathrm{KH}_{2} \mathrm{PO}_{4}\right)$. Dunaliella salina kering seberat 0,6 gram dihaluskan dengan menggunakan mortar dan setelah halus tambahkan pelarut $10 \mathrm{~mL}$. Kemudian sampel dimasukkan ke tabung sentrifuse untuk diinkubasi selama 14 - 16 jam dalam refrigenerator. Selanjutnya adalah filtrat yang diperoleh disentrifugasi dengan menggunakan spektrofotometer pada kisaran panjang gelombang $562 \mathrm{~nm}, 620$ $\mathrm{nm}$, dan $652 \mathrm{~nm}$ (Sedjati, 2012). Perhitungan kadar fikosianin, dan allofikosianin diadaptasi dari metode Bennett dan Bogorad (1973). 


\section{HASIL DAN PEMBAHASAN}

\section{Kadar Pigmen Dunaliella salina}

Kadar pigmen fikosianin paling tinggi ada pada perlakuan salinitas $35 \mathrm{pp}$ sebesar 11,341 mg/gram, sedangkan kandungan fikosianin terendah ada pada perlakuan salinitas 40 ppt sebesar 3,593 mg/gram. Kadar pigmen allofikosianin paling tinggi juga terjadi pada perlakuan salinitas 35 ppt sebesar 9,644 mg/gram, sedangkan kandungan allofikosianin terendah ada pada perlakuan salinitas 40 ppt sebesar 2,411 mg/gram (Gambar 1).

Hasil uji menunjukkan bahwa perlakuan salinitas berpengaruh nyata $(P<0,05)$ terhadap kandungan pigmen klorofil fikosianin dan allofikosianin mikroalga $D$. salina. Hal tersebut diduga karena salinitas berpengaruh terhadap tekanan osmotik yang mempengaruhi pembentukan pigmen. Menurut Golldack et al (1995) bahwa stressing salinitas baik dibawah maupun diatas salinitas normal akan menyebabkan menurunkan sintesa pigmen pada mikroalga.

Kadar pigmen fikobiliprotein (ficosianin dan allofikosianin) yang tinggi terjadi pada perlakuan dengan salinitas yang relatif tinggi (35 ppt), hal ini diduga dikarenakan pada pada salinitas yang tinggi akan mengakibatkan menurunnya intensitas cahaya yang masuk pada media pemeliharaan tidak optimal, sehingga akan mengakibatkan turunnya kandungan pigmen phycobiliprotein pada salinitas diatas dan dibawah 35 ppt. Menurut Manirafasha, $\mathrm{E}$ et al (2016) Kebanyakan microalgae mengakumulasi dari pigmen phycobiliprotein pada saat terjadinya stressing faktor lingkungan medianya. Produksi pigmen phycobiliprotein akan semakin tinggi bila intensitas cahaya yang masuk optimal. Hasil penelitian Lamela (2000) mengenai produksi pigmen phycocyanin dari Spirulina maxima yang dibudidayakan di air laut menunjukkan bahwa semakin tinggi salinitas media, maka akumulasi pigmen phycocyanin akan semakin meningkat, sedangkan pigmen chlorophyll-a menurun.

Pada salinitas tinggi sel mikroalga mampu bertahan hidup karena adanya bantuan gliserol yang berfungsi sebagai mendukung tekanan osmotik untuk menyeimbangkan proses osmolaritas pada sel bagian luar (extracellular). Salinitas yang tinggi menyebabkan berkurangnya cairan yang ada pada sel sehingga akan mempengaruhi proses fotosintesis (Avron, 1992). Sedangkan D. salina tidak memiliki dinding sel, akan tetapi sel dilindungi oleh membran plasma tipis atau disebut dengan periplast yang memungkinkan dapat mengalami perubahan ukuran dan bentuk sel secara cepat terhadap tekanan osmotik (Venkatesan et al., 2013).

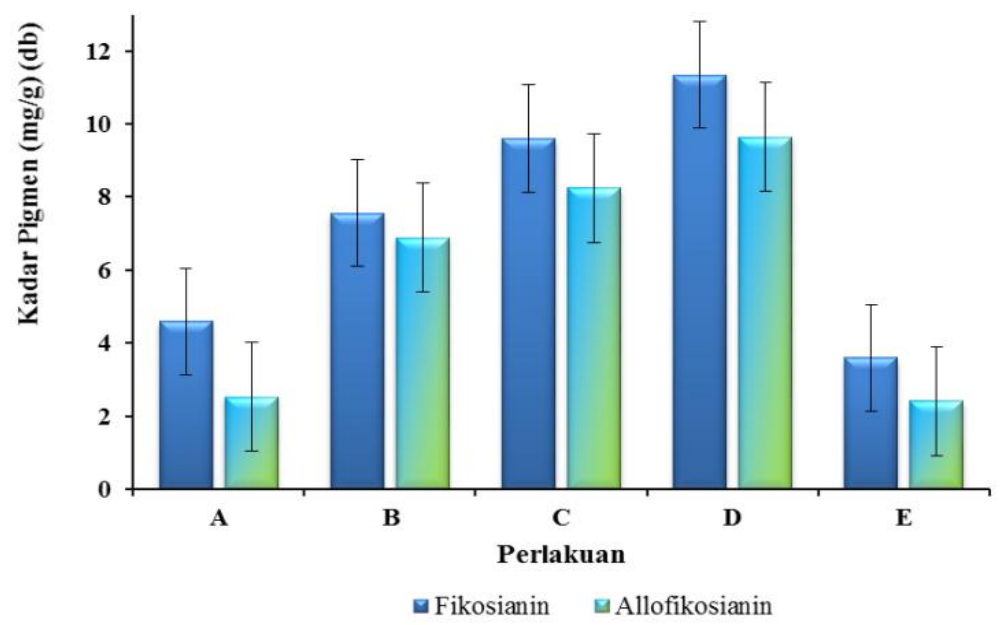

Gambar 1. Histogram Kadar Pigmen (mg/gram \pm SD) D. salina pada Perlakuan Salinitas yang Berbeda. Keterangan: A: Salinitas 20 ppt; B: Salinitas 25 ppt; C: Salinitas 30 ppt; D: Salinitas 35 ppt; E: Salinitas 40 ppt. 


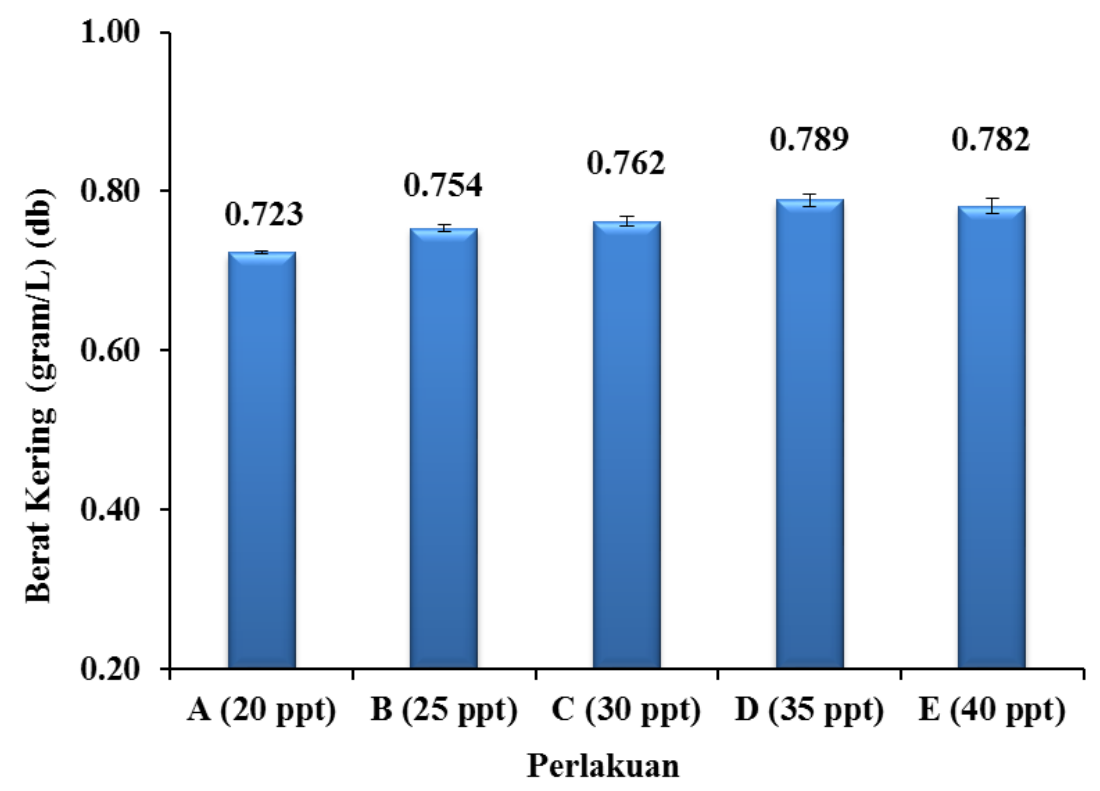

Gambar 2. Histogram Biomassa Kering (gram/L \pm SD) D. salina pada Perlakuan Salinitas yang Berbeda

\section{Biomassa Dunaliella salina}

Biomassa Dunaliella salina pada kultur dengan salinitas berbeda menghasilkan biomassa tertinggi pada perlakuan salinitas $35 \mathrm{ppt}(0,789 \mathrm{mg} / \mathrm{L})$, sedangkan terendah pada perlakuan salinitas $20 \mathrm{ppt}(0,723 \mathrm{mg} / \mathrm{L})$ (Gambar 2).

Hasil uji menunjukkan bahwa perlakuan salinitas berpengaruh terhadap biomassa kering $D$. salina. Hal tersebut diduga karena berkaitan dengan variasi ukuran sel $D$. salina dan kepadatan sel serta laju pertumbuhan yang disebabkan oleh adanya perbedaan salinitas. Ukuran sel yang bervariasi dikarenakan sesuai dengan kondisi pertumbuhannya dan perubahan lingkungan seperti salinitas. Menurut Adenan (2013) bahwa salinitas memiliki peran pada kelangsungan hidup mikroalga dan dapat menyebabkan penghambatan aktivitas metabolisme akibat menurunnya fotosintesis. Sedangkan Huang et al., (2011) menyatakan baha mikroalga memanfaatkan cahaya, energi dan nutrisi yang ada untuk memproduksi biomassa.

Hasil uji statistik menunjukkan bahwa biomassa tertinggi yang dihasilkan oleh $D$. salina ada pada perlakuan salinitas 35 ppt, hal ini diduga bahwa pada salinitas $35 \mathrm{ppt}$ merupakan salinitas optimum untuk mendapatkan biomassa yang besar. Menurut Ferraris et al., (1986) bahwa salinitas merupakan salah satu faktor lingkungan yang berpengaruh pada organisme yang berdampak terhadap osmoregulasi dan bioenergetik organisme akuatik. Salinitas memiliki pengaruh pada pengaturan ion internal yang secara langsung membutuhkan energi untuk dapat melakukan transpor aktif ion - ion guna mempertahankan lingkungan internal. Sehingga, hal ini mempengaruhi pada proses fisiologis sehingga metabolisme akan terganggu, gangguan metabolisme ini akan menurunkan kuantitas dan kualitas produksi biomassa.

Secara tidak langsung, faktor yang mempengaruhi produksi biomassa kering adalah pengaruh cahaya yang diakibatkan adanya perbedaan salinitas. Menurut Mitra et al. (2015) menunjukkan bahwa pada saat keadaan gelap tidak diketahui adanya pertambahan biomassa dengan produksi EPA dan lipid yang rendah. Walaupun tidak ada pertambahan biomassa, tetapi masih bertahan hidup pada kondisi gelap dan kandungan lipid masih bisa diamati. Produksi biomassa cenderung diikuti oleh kandungan klorofil a dan karotenoid yang terkena cahaya dengan waktu yang 
berbeda. Dilaporkan bahwa pada konsentrasi yang rendah dan keadaan gelap menghasilkan klorofil a dan karotenoid yang tinggi (Fields et al., 2014).

\section{KESIMPULAN}

Salinitas berpengaruh nyata terhadap kadar pigmen nonpolar (fikosianin dan alofikosianin) pada mikroalga Dunaliella salina. Kadar pigmen nonpolar dan biomassa tertinggi dicapai pada salinitas $35 \mathrm{ppt}$

\section{DAFTAR PUSTAKA}

Adenan, N.S., F. Md. Yusoff, M. Shariff. 2013. Effect of Salinity and Temperature on the Growth of Diatoms and Green Algae. Journal of Fisheries and Aquatic Science, 8(2): 397-404.

Avron, M. 1992. Osmoregularity, in Dunaliella: Physiology, Biochemistry and Biotechnology, edited by M. Avron dan A Ben Amotz. CRC Press, Boca Raton, Florida, 135-164.

Azimatun Nur, MM. 2014. Potensi Mikroalga sebagai Sumber Pangan Fungsional di Indonesia (overview). Eksergi, 11 (2), 01 06.

Barra, L., Chandrasekaran, R., Corato, F., Brunet, C., 2014. The challenge of ecophysiological biodiversity for biotechnological applications of marine microalgae. Mar. Drugs 12 , 1641 e1675.

Eriksen, NT. 2016. Research Trends in the Dominating Microalgal Pigments, $\beta$ Carotene, Astaxanthin, and Phycocyanin Used in Feed, in Foods, and Health Applications. Journal of Nutrition and Food Sciences. 6(3).

Ferraris, R.P., F.D.P. Estepa, J.M. Ladja, E.G. De Jesus. 1986. Effect of Salinity on The Osmotic, Chloride, Total Protein and Calcium Concentraion In the Hemolymph of The Prawn, Penaeus monodon Fabricius. Comp Biochem Physiol., 83A(4):701-708.

Fields, M.W., A.Hise, E.J. Lohman, T. Bell, R.D. Gardner, L. Corredor, K. Moll, B.M. Peyton, G.W. Characklis, R. Gerlach. 2014. Sources and Resources: Importance of Nutrients, Resource
Allocation, and Ecology in Microalgal Cultivation for Lipid Accumulation, Appl. Microbiol. Biotechnol, 98:48054816.

Gu, Na., Q. Lin, G. Li, Y. Tan, L. Huang, J. Lin. 2012. Effect of Salinity on Growth, Biochemical Composition and Lipid Productivity of Nannochloropsis oculata CS 179. Eng Life Sci., 12(5):1-7.

Golldack, D; Karl-Josef Dietz and Hartmut Gimmleri. 1995.The Effects of Sudden Salt Stress on Protein Synthesis in the Green Alga Dunaliella parva. J. Plant Physiol. Vol. 146. pp. 508-514.

Ghoshal, D., Mach, D., Agarwal, M., Goyal, A. (2002). Osmoregulatory isoform of dihydroxyacetone phosphate reductase from Dunaliella tertiolecta: Purification and characterization. Protein Expr. Purif., 24: 404-411.

Hadiyanto., Azim, Maulana., 2012, Mikroalga: Sumber Pangan dan Energi Masa Depan, edisi pertama, Undip Press, Semarang.

Huang, W.W., B.Z. Dong, Z.P. Cai dan S.S. Duan. 2011. Growth Effect on Mixed Culture of Dunaliella salina and Phaeodactylum trucornutum Under Different Inoculation Densities and Nitrogen Concentrations. Afr. J. Biotechnol., 10:13164-13174.

Jahnke, L. S. and A.L. White. 2003. Longterm Hyposaline and Hypersaline Stresses Produce Distinct Antioxidant Responses in The Marine Alga Dunaliella tertiolecta, Plant Physiol.

Lamela, T. 2000, Phycocyanin Production in Seawater Culture of Arthospira maxima. Ciencias Marinas, 26(4):607619.

Loseva a, N.L, A.Ju. Alyabyev, L.Kh. Gordon, I.N. Andreyeva,O.P. Kolesnikov, A.A. Ponomareva, R.B. Kemp. 2007. The effect of AgNO3 on the bioenergetic processes and the ultrastructure of Chlorella and Dunaliella cells exposed to different saline conditions. Thermochimica Acta 458 (2007) 71-76

Manirafasha E a, Theoneste Ndikubwimanaa, Xianhai Zengb,c, Yinghua Lua,c, Keju Jing. 2016. Phycobiliprotein: Potential microalgae derived pharmaceutical and 
biological reagent. Biochemical Engineering Journal 109 (2016) 282-296. Mitra, M., S.K. Patidar, B. George, F. Shah, S. Mishra. 2015. A Euryhaline Nannochloropsis gaditana with Potential for Nutraceutical (EPA) and Biodiesel Production. Algal Research 8., 161-167.

Rao, A.R., C. Dayananda, R., Sarada, T.R., Shamala dan G.A. Ravishankar. 2007. Effect of Salinity on Growth of Green Algae Botryococcus braunii and its Constituens. Bioresour. Technol., 98:560564.

Rodriguez, JC., M.C. Ceron-Garcia, J.M. Fernandez-Sevilla, and E. MolinaGrima. 2015. The influence of culture conditions on biomass and high value product generation by
Nannochloropsis gaditana in aquaculture. Jounal of Algal Research (11): 63-73

Sedjati, S., Yudiati, E., dan Suryono. 2012. Profil Pigmen Polar dan Non Polar Mikroalga Laut Spirulina sp. dan Potensinya sebagai Pewarna Alami. Jurnal Ilmu Kelautan 17(3): 176-181.

Venkatsen, S., M.S. Swamy, C. Senthil, S. Bhaskar and R. Rengasamy. 2013. Culturing Marine Green Microalgae Dunaliella salina Teod. And Dunaliella tertiolecta Masjuk in Dewalne's Medium for Valuable Feeds Stock. Journal of Modern Biotechnology., 2(II):40-45. 